\title{
Catalytic Enantioselective Aza-Reformatsky Reaction with Cyclic Imines
}

\author{
Lode De Munck, ${ }^{[a]}$ Carlos Vila*[a] M. Carmen Muñoz ${ }^{[b]}$ and José R. Pedro*[a]
}

\begin{abstract}
A catalytic highly enantioselective aza-Reformatsky reaction with cyclic aldimines and ketimines for the synthesis of chiral $\beta$-amino esters with good yields and excellent enantioselectivities is reported. A readily available diaryl prolinol is used as a chiral ligand, $\mathrm{ZnMe}_{2}$ as a zinc source and ethyl iodoacetate as reagent in the presence of air atmosphere. The reaction with cyclic ketimines generates a quaternary stereocenter with excellent levels of enantioselectivity. Furthermore, five-membered $\mathrm{N}$-sulfonyl ketimines were used as electrophiles with good enantiomeric excesses, under the optimized reaction conditions. Moreover, several chemical transformations were performed with the chiral $\beta$-amino esters.
\end{abstract}

The classical Reformatsky reaction, discovered in 1887, provides a convenient synthesis of $\beta$-hydroxy esters through a zinc mediated reaction between $\alpha$-haloacetates and aldehydes or ketones. $^{[1,2]}$ Since its introduction, more than 130 years ago, this reaction is a powerful methodology for $\mathrm{C}-\mathrm{C}$ bond formation with a wide application in organic synthesis, due to the remarkable functional group tolerance and mild reaction conditions. In recent years, Reformatsky reaction has achieved renewed interest from the development of a homogeneous Reformatsky reaction based in the use of $\mathrm{Me}_{2} \mathrm{Zn}$ or $\mathrm{Et}_{2} \mathrm{Zn}$ introduced by Honda and coworkers in 2000. ${ }^{[3]}$ In this context, asymmetric homogeneous Reformatsky reactions are known, but generally stoichiometric amounts of chiral ligands are used. ${ }^{[4]}$ Recently, advances in the development of catalytic enantioselective methodologies for Reformatsky reactions ${ }^{[5]}$ for the synthesis of chiral $\beta$-hydroxy esters, were introduced by the groups of Cozzi[i] and Feringa ${ }^{[7]}$ (Scheme 1a). Imines can be used as electrophiles for the Reformatsky reaction instead of aldehydes or ketones, as Gilman and Speeter disclosed 70 year ago. ${ }^{[8,9]}$ However, this transformation is problematic, because often affords a mixture of $\beta$-amino esters and $\beta$-lactams. Consequently, the catalytic enantioselective azaReformatsky reaction is scarcely explored, despite its potential for the synthesis of chiral $\beta$-amino acids. ${ }^{[10]}$ Chiral $\beta$-amino acids are an extremely important class of compounds in organic and medicinal chemistry. They are key structural elements of peptides or peptidomimetics. ${ }^{[11]}$ Furthermore, $\beta$-amino acids are intermediates or precursors of biologically active compounds such as $\beta$-lactams, the most important class of antibiotics. ${ }^{[12]}$ Only one example of catalytic enantioselective aza-Reformatsky reaction is described in the literature. Cozzi, in 2006, ${ }^{[13]}$ described the first catalytic enantioselective one-pot three-component aza-

[a] Lode De Munck, Dr. C. Vila and Prof. Dr. J. R. Pedro Departament de Química Orgànica, Facultat de Química, Universitat de València, Dr. Moliner 59, 46100 Burjassot, València (Spain) Fax: (+34) 963544328 E-mail: carlos.vila@uv.es,jose.r.pedro@uv.es

[b] Prof. Dr. M. C. Muñoz

Departament de Física Aplicada, Universitat Politècnica de València, Camino de Vera s/n, 46022 València (Spain)

Supporting information for this article is given via a link at the end of the document.((Please delete this text if not appropriate))
Reformatsky using $\mathrm{N}$-methylephedrine $(20-30 \mathrm{~mol} \%)$ as chiral ligand obtaining highly enantioenriched $\beta$-amino esters (Scheme 1b). ${ }^{[14]}$ However, in order to have high ee, o-phenoxyaniline was used, and the version with ketimines was unexplored in this report. In the context of aza-Reformatsky reaction, the addition of $\alpha$ haloacetates to cyclic imines is unkown, despite its potential for the synthesis of optically pure $\mathrm{N}$-heterocycles. Furthermore any ketimine has been used in such reactions. The use of this kind of electrophiles represents a synthetic challenge owing to their low reactivity, steric bulkiness and the associated difficulty with stereochemical control. Sulfamidates represent an interesting class of amine derivatives present in some pharmaceuticals and biological active compounds ${ }^{[15]}$ and also play an important role as building blocks for organic synthesis. ${ }^{[16]}$ We envisioned the use of cyclic imines such as benzoxathiazine 2,2-dioxides as electrophiles in the aza-Reformatsky reaction (Scheme 1c), because these compounds have a rigid structure that reduces the conformational mobility and avoid the $E / Z$ isomerization, facilitating the stereodifferentiation and making them optimum partners for asymmetric catalysis. Recently, these cyclic imines have proven to be versatile building blocks in asymmetric synthesis and different enantioselective addition of nucleophiles have been described for the synthesis of chiral benzo-fused cyclic sulfamidate heterocycles. ${ }^{[17]}$

$$
\text { a) Catalytic Enantioselective Reformatsky Reaction with Aldehydes and Ketones }
$$
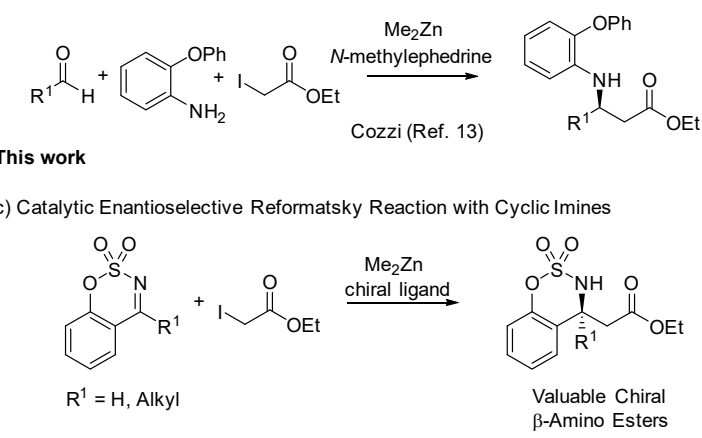

Scheme 1. Catalytic enantioselective Reformatsky reactions.

Herein, we disclose our results on the enantioselective addition of ethyl iodoacetate mediated by $\mathrm{Me}_{2} \mathrm{Zn}$ to cyclic imines (aldimines and ketimines). This represents the first catalytic enantioselective aza-Reformatsky reaction with ketimines. Notably, this protocol is operated under mild reaction conditions and delivers the chiral functionalized cyclic sulfamidates in high yields and high to excellent enantiomeric excesses. 
We started our studies with the reaction of ethyl iodoacetate $(2)^{[18]}$ with cyclic benzo[e][1,2,3]-oxathiazine 2,2-dioxide (1a) in the presence of chiral amino alcohols and mediated by $\mathrm{Me}_{2} \mathrm{Zn}$ (Table 1). When quinine (L1) was used as a chiral ligand (entry 1 , Table 1 ), full conversion was achieved obtaining the corresponding $\beta$ amino ester $3 \mathbf{a}$ with $84 \%$ yield, but as a racemic mixture. After, we tested $N$-methyl ephedrine $\mathbf{L 2}$, used by Cozzi, ${ }^{[14]}$ and the corresponding product 3a was obtained with good yield but poor enantiomeric excess (entry 2, Table 1).

Table 1. Optimization of the reaction conditions.
(S)-diphenylprolinol (L3) ${ }^{[19]}$ bearing a secondary amine. To our delight, when 20 mol\% of ligand L3 was used, product 3a was gained with good yield $(74 \%)$ and with a promising level of enantioselectivity $(75 \%$ ee, entry 3$)$. We try to decrease the amount of $\mathrm{Me}_{2} \mathrm{Zn}$ to 3 equivalents, but unfortunately the yield and the enantiomeric excess were lower (entry 4). Furthermore, $\mathrm{Et}_{2} \mathrm{Zn}$ was used as the zinc source in the model reaction (entry 5 ), obtaining better yield (88\%) but with considerably lower enantioselectivity $(60 \%$ ee). Consequently, we followed the optimization of the reaction conditions using 7 eq. of $\mathrm{Me}_{2} \mathrm{Zn}$. A solvent screening (entries 6-10) showed that ethereal solvents performed the reaction with the best enantioselectivities. $\mathrm{Et}_{2} \mathrm{O}$ and MTBE, afforded the product 3a with the same ee $(75 \%$ ee), but the best yield $(91 \%)$ was obtained when MTBE was used as a solvent. Therefore, MTBE was chosen as a solvent for a temperature screening (entries 11-12), observing the best enantioselectivity at $0{ }^{\circ} \mathrm{C}(80 \%$ ee $)$. At this point, our efforts to optimize the reaction conditions were aimed at exploring other commercially available diarylprolinol ligands (L4-L6, entries13$15)$ in order to improve the enantiomeric excess. Gratifyingly, (S)a,a-bis[3,5-bis(trifluoromethyl)phenyl]-2-pyrrolidinemethanol L5 exhibited the best enantioselectivity affording product $3 a$ in $86 \%$ yield and $92 \%$ ee. A reduction of the catalyst load to $10 \mathrm{~mol} \%$ had a slightly deleterious effect on the enantioselectivity of the reaction $(87 \%$ ee, entry 16$)$.

\begin{tabular}{|c|c|c|c|c|c|}
\hline Entry ${ }^{[a]}$ & $\mathbf{L}(\mathrm{X}$ mol\%) & Solvent & $\mathrm{T}\left({ }^{\circ} \mathrm{C}\right)$ & Yield $(\%)^{b}$ & $\operatorname{Ee}(\%)^{\mathrm{c}}$ \\
\hline 1 & L1 (20 mol\%) & $\mathrm{Et}_{2} \mathrm{O}$ & rt & 84 & 0 \\
\hline 2 & L2 (20 mol\%) & $\mathrm{Et}_{2} \mathrm{O}$ & $\mathrm{rt}$ & 79 & $10^{d}$ \\
\hline 3 & L3 (20 mol\%) & $\mathrm{Et}_{2} \mathrm{O}$ & $\mathrm{rt}$ & 74 & 75 \\
\hline $4^{e}$ & L3 (20 mol\%) & $\mathrm{Et}_{2} \mathrm{O}$ & $\mathrm{rt}$ & 70 & 73 \\
\hline $5^{f}$ & L3 (20 mol\%) & $\mathrm{Et}_{2} \mathrm{O}$ & $\mathrm{rt}$ & 88 & 60 \\
\hline 6 & L3 (20 mol\%) & MTBE & $\mathrm{rt}$ & 91 & 75 \\
\hline 7 & L3 (20 mol\%) & $\mathrm{Pr}_{2} \mathrm{O}$ & $\mathrm{rt}$ & 87 & 69 \\
\hline 8 & L3 (20 mol\%) & THF & $\mathrm{rt}$ & 42 & 28 \\
\hline 9 & L3 (20 mol\%) & Toluene & $\mathrm{rt}$ & 95 & 70 \\
\hline 10 & L3 (20 mol\%) & $\mathrm{CH}_{2} \mathrm{Cl}_{2}$ & $\mathrm{rt}$ & 95 & 55 \\
\hline 11 & L3 (20 mol\%) & MTBE & 0 & 74 & 80 \\
\hline 12 & L3 (20 mol\%) & MTBE & -10 & 96 & 77 \\
\hline 13 & L4 (20 mol\%) & MTBE & 0 & 88 & 79 \\
\hline 14 & L5 (20 mol\%) & MTBE & 0 & 86 & 92 \\
\hline 15 & L6 (20 mol\%) & MTBE & 0 & 96 & 80 \\
\hline 16 & L5 (10 mol\%) & MTBE & 0 & 89 & 87 \\
\hline
\end{tabular}

[a] Reaction conditions: $1 \mathrm{a}(0.1 \mathrm{mmol}), 2(0.20 \mathrm{mmol}), \mathrm{Me}_{2} \mathrm{Zn}(7 \mathrm{eq}$.$) and$ ligand $(\mathrm{x} \mathrm{mol} \%)$ in $1 \mathrm{~mL}$ of solvent under air atmosphere. [b] Isolated yield after column chromatography. [c] Determined by HPLC using chiral stationary phase. [d] Opposite enantiomer was obtained. [e] 3 equivalents of $\mathrm{Me}_{2} \mathrm{Zn}$ were used. [f] 7 equivalents of $\mathrm{Et}_{2} \mathrm{Zn}$ were used.

In view of the poor results with chiral aminoalcohols bearing a tertiary amine, we focused our attention in the readily available

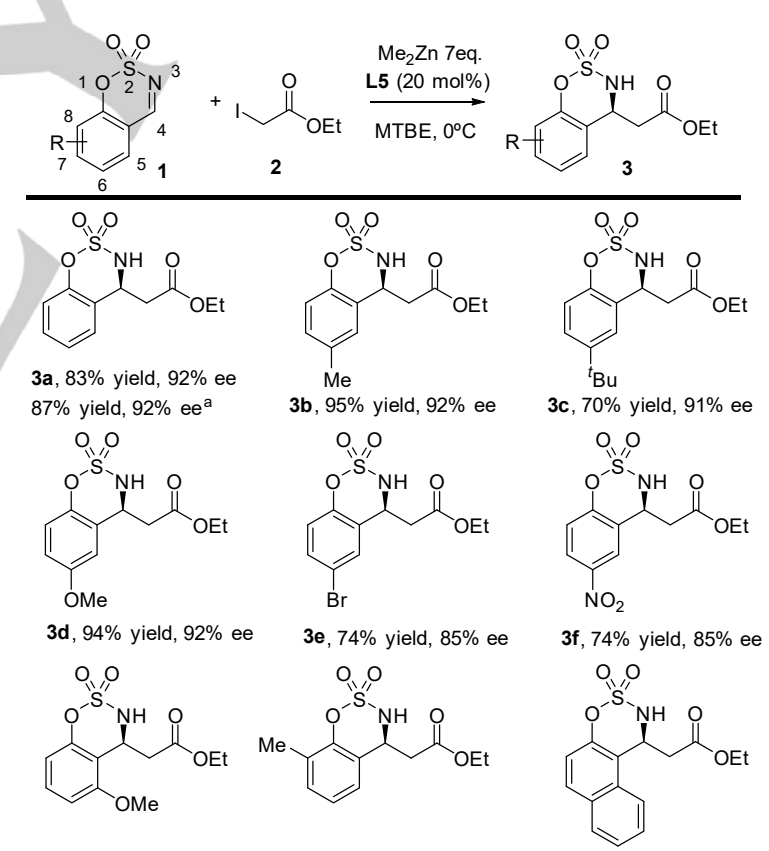

3g, $70 \%$ yield, $90 \%$ ee $\quad 3$ h, $88 \%$ yield, $91 \%$ ee<smiles>CCOC(=O)CC1NS(=O)(=O)Oc2c(Br)cc(Br)cc21</smiles>

3j, $73 \%$ yield, $88 \%$ ee

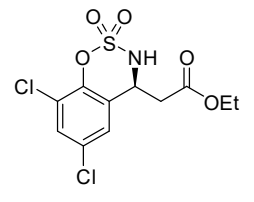

3k, $97 \%$ yield, $79 \%$ ee
Scheme 2. Scope of the aza-Reformatsky reaction with cyclic aldimines: 1 (0.1 $\mathrm{mmol}), 2$ (0.2 mmol), Me $2 \mathrm{Zn}$ (7 eq.) and L5 (20 mol\%) in $3 \mathrm{~mL}$ of MTBE. Isolated yields after column chromatography. Enantiomeric excesses were determined by HPLC using chiral stationary phase. ${ }^{a} 0.4 \mathrm{mmol}$ reaction scale. 
With the optimized conditions in hand, the aza-Reformatsky reactions of a variety of aldimines 1 with ethyl iodoacetate were carried out (Scheme 2). Various substituents in the 6-position in the phenyl ring of the cyclic imines $\mathbf{1}$, such as methyl, tert-butyl, methoxy, bromo or nitro, were well tolerated under the reaction conditions, and the corresponding chiral $\beta$-amino esters 3 were obtained with good yields (70-95\%) and high enantioselectivities (85-92\%). Moreover, substituents in other positions such as 5 and 8 , and even naphthyl rings, were well tolerated giving the reaction product with great enantiomeric excesses $(90-93 \%$ ee). Furthermore, cyclic imines $(\mathbf{1} \mathbf{j}-\mathbf{1 k})$ with two substituents that provide steric hindrance, were suitable substrates for the azaReformatsky reaction, affording good enantiomeric excess (88\% and $79 \%$ ee).

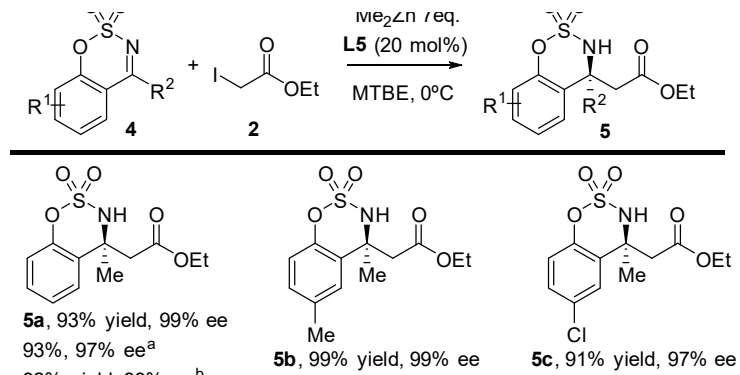
$92 \%$ yield $99 \%$ ee

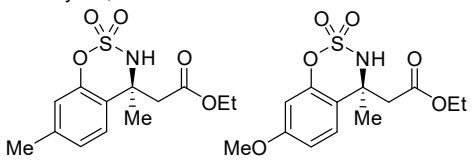

5d, $91 \%$ yield, $98 \%$ ee

3e, $94 \%$ yield, $98 \%$ ee

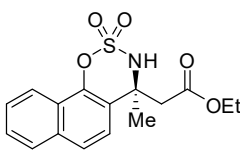<smiles>CCOC(=O)CC1NS(=O)(=O)Oc2ccccc21</smiles>

$\mathbf{5 g}, 87 \%$ yield, $98 \%$ ee

5 h, $92 \%$ yield, $98 \%$ ee

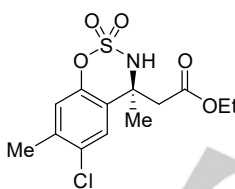

$\mathbf{5 f}, 87 \%$ yield, $96 \%$ ee

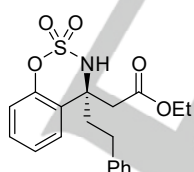

$5 \mathbf{i}, 98 \%$ yield, $97 \%$ ee
Scheme 3. Scope of the aza-Reformatsky reaction with cyclic ketimines: 4 (0.1 $\mathrm{mmol}), 2(0.2 \mathrm{mmol}), \mathrm{Me}_{2} \mathrm{Zn}$ (7 eq.) and L5 (20 mol\%) in $3 \mathrm{~mL}$ of MTBE. Isolated yields after column chromatography. Enantiomeric excesses were determined by HPLC using chiral stationary phase. ${ }^{a} 10 \mathrm{~mol} \%$ of $\mathbf{L} 5$ was used. ${ }^{\mathrm{b}} 0.4 \mathrm{mmol}$ reaction scale.

Once we have studied the aza-Reformatsky reaction with a variety of aldimines 1 , we decided to study the more challenging ketimines 4 (Scheme 3). To the best of our knowledge, ketimines have been never used in catalytic enantioselective azaReformatsky reaction probably due to their low reactivity and low control of stereoselectivity. However, we decided to test under the reaction conditions the corresponding 4methylbenzo[e][1,2,3]oxathiazine 2,2-dioxide 4 a derived from ortho-hydroxyacetophenone. To our delight, compound 4a reacted smoothly and the corresponding $\beta$-amino ester $\mathbf{5 a}$, bearing a quaternary stereocenter was gained with high yield $(93 \%)$ and excellent enantioselectivity $(99 \%$ ee). When the catalyst loading was reduced to $10 \mathrm{~mol} \%$, the enantioselectivity was still excellent $(97 \%$ ee). Encouraged by the results for the
Reformatsky reaction with ketimine $\mathbf{4 a}$, we decided to expand the methodology to other cyclic ketimines. A range of substituted ketimines efficiently participated in the reaction using the optimized conditions with excellent results in terms of reactivity and enantioselectivity. Introduction of substituents in the aromatic ring of the ketimines revealed that both electron-donating and withdrawing groups were well tolerated at various positions on the ring (5b-5f, 96-99\% ee). A naphthyl substrate $(\mathbf{4 g})$ also gave the corresponding product $\mathbf{5 g}$ with $87 \%$ yield and $98 \%$ of enantiomeric excess. Furthermore, we explored other alkyl substituents (Et or $\mathrm{PhCH}_{2} \mathrm{CH}_{2}$ ) in 4-position of ketimines 4, giving the corresponding $\beta$-amino esters $\mathbf{5 h}$ and $\mathbf{5 i}$ with 98 and $97 \%$ ee, respectively.

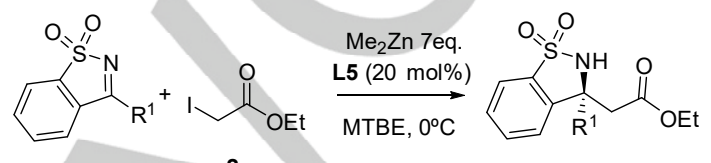

6a, $R^{1}=M e$

6b, $R^{1}=E t$
$7 a, R^{1}=$ Me, $86 \%$ yield, $85 \%$ ee

7b, $R^{1}=$ Et, $79 \%$ yield, $70 \%$ ee
Scheme 4. Enantioselective aza-Reformatsky reaction with cyclic $N$-sulfonyl ketimines 6 .

Having stablished the highly enantioselective azaReformatsky reaction of six-membered cyclic ketimines, we turned our attention to five-membered cyclic $N$-sulfonyl ketimines for the synthesis of chiral benzosultams. The enantioselective aza-Reformatsky reaction with cyclic ketimines 6 underwent smoothly, and the corresponding chiral $\beta$-amino ester 7 were obtained with good yields and enantioselectivities (Scheme 4).

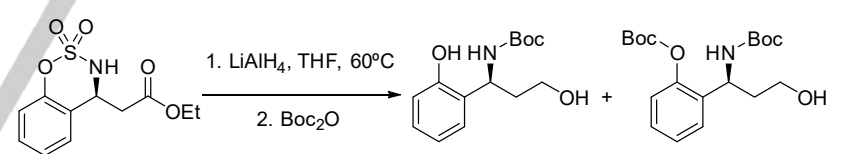
3a $92 \%$ ee $\quad \mathbf{8 a}, 21 \%$ yield, $92 \%$ ee $\quad \mathbf{8 b}, 33 \%$ yield, $92 \%$ ee

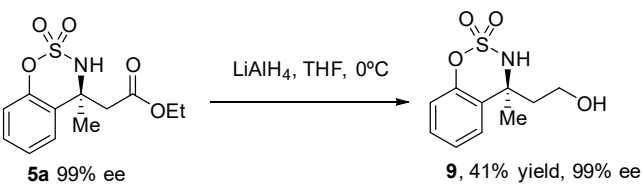<smiles>[R]C1NS(=O)(=O)Oc2ccccc21</smiles>
3a, $\mathrm{R}=\mathrm{H}, 92 \%$ ee
$10, \mathrm{R}=\mathrm{H}, 91 \%$ yield, $92 \%$ ee
$12,72 \%$ yield, $98 \%$ ee 5a, $\mathrm{R}=\mathrm{Me}, 99 \%$ ee $11, \mathrm{R}=\mathrm{Me}, 99 \%$ yield, $98 \%$ ee

Scheme 5. Synthetic transformations. Boc= tert-Butyloxycarbonyl; THF= Tetrahydrofuran; $\quad \mathrm{EDCl}=\quad$ 1-Ethyl-3-(3-dimethylaminopropyl)carbodiimide; $\mathrm{NMM}=\mathrm{N}$-Methylmorpholine.

To highlight the synthetic utility, we have applied several chemical transformations for the synthesis of interesting chiral compounds (Scheme 5). For example, the reduction of the ester 
moiety and ring opening of the benzosulfamidate $3 \mathbf{a}$, give the aminoalcohols $\mathbf{8} \mathbf{a}$ and $\mathbf{8 b}$, with moderate yield but preserving the enantiomeric excess. Chiral amino alcohol $\mathbf{9}$, was synthesized by reduction of the $\beta$-amino ester at low temperature. The $\beta$-amino acids 10 and 11 were prepared by simple saponification with good yields and without loss of optical purity. Furthermore, the chiral $\beta$ lactam 12 with three fused cycles and a quaternary stereocenter was prepared from the $\beta$-amino acid 11 , in $72 \%$ yield and $98 \%$ ee.

In order to explain our results, we proposed the catalytic cycle depicted in Scheme 6. This catalytic system is based on the catalytic cycle proposed by Cozzi ${ }^{[6,13]}$ and Feringa ${ }^{[7]}$ for enantioselective Reformatsky reactions and the zinc intermediates proposed by Noyori. ${ }^{[20]}$ Ligand $\mathbf{L} \mathbf{5}$ is deprotonated by $\mathrm{Me}_{2} \mathrm{Zn}$ to generate the complex $\mathbf{A}$, which is in equilibrium with the dimer $\mathbf{B}$. The addition of ethyl iodoacetate is accelerated in the presence of $\mathrm{Me}_{2} \mathrm{Zn}$ and oxygen, through a cycle where $\mathrm{Me}_{2} \mathrm{Zn}$ is acting as a source of methyl radicals which react with ethyl iodoacetate giving ethyl acetate radicals. ${ }^{[21-23]}$ Complex $\mathbf{C}$ is generated after the addition of the ethyl acetate radical to dimer B. We believe that the active catalytic species is the complex $\mathbf{C}$ due to the moderate positive non-linear effect observed when correlating the enantiopurity of the aza-Reformatsky product 3a with the enantiopurity of ligand $\mathbf{L 5}{ }^{[24]}$ Complex $\mathbf{C}$ assisted the nucleophilic addition of the ethyl iodoacetate to the Si face ${ }^{[25,26]}$ of the cyclic imine affording the $\beta$-amino ester and regenerating the dimer B.

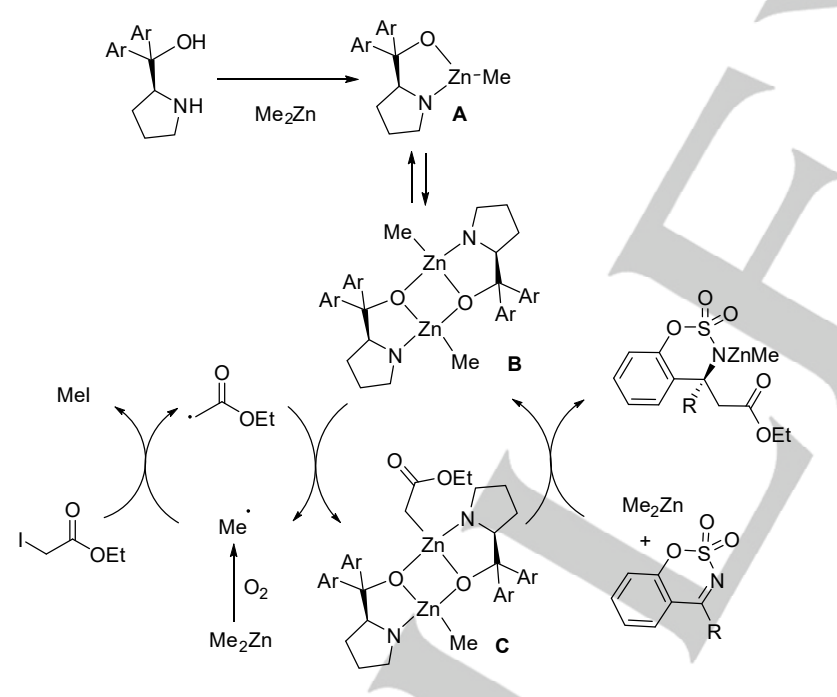

Scheme 6. Proposed catalytic cycle for the aza-Reformatsky reaction.

We have developed the first highly enantioselective catalytic aza-Reformatsky reaction with cyclic imines. In our methodology, cyclic aldimines and ketimines can be used as electrophiles obtaining chiral $\beta$-amino esters with excellent enantiomeric excesses. Our approach represents the first catalytic enantioselective aza-Reformatsky reaction with ketimines, leading to $\beta$-amino esters bearing a quaternary stereocenter. Moreover several transformations have been done with the corresponding chiral $\beta$-amino esters obtained.

\section{Acknowledgements}

Financial support from the MINECO (Gobierno de España; CTQ2013-47494-P). L. D. M. thanks the Generalitat Valenciana for a predoctoral grant. C.V. thanks MINECO for a JdC contract. Access to NMR, MS and X-ray facilities from the Servei central de suport a la investigació experimental (SCSIE)-UV is also acknowledged.

Keywords: asymmetric catalysis • Reformatsky reaction $\bullet$ zinc $•$ cyclic ketimines $\bullet \beta$-amino ester

[1] S. Reformatsky, Ber. Dtsch. Chem. Ges. 1887, 20, 1210-1211.

[2] a) R. Ocampo, W. R. Dolbier Jr., Tetrahedron 2004, 60, 9325-9374; b) E. Ender, Tetrahedron 1992, 48, 9577-9648; c) C. M. R. Ribeiro, F. M. Cordeiro de Farias, Mini-Rev. Org. Chem. 2006, 3, 1-10; d) P. G. Cozzi, Angew. Chem. 2007, 119, 2620-2623; Angew. Chem. Int. Ed. 2007, 46, 2568-2571.

[3] K. Kanai, H. Wakabayashi, T. Honda, Org. Lett. 2000, 2, 2549-2551.

[4] a) J. D. Clark, G. A. Weisenburger, D. K. Anderson, P.-J. Colson, A. D. Edney, D. J. Gallagher, H. P. Kleine, C. M. Knable, M. K. Lantz, C. M. V. Moore, J. B. Murphy, T. E. Rogers, P. G. Ruminski, A. S. Shah, N. Storer, B. E. Wise, Org. Process Res. Dev. 2004, 8, 51-61; b) D. P. G. Emmerson, W. P. Hems, B. G. Davis, Tetrahedron: Asymmetry 2005, 16, 213-221; c) F. Orsini, G. Sello, A. M. Manzo, E. M. Lucci, Tetrahedron: Asymmetry 2005, 16, 1913-1918; d) R. J. Kloetzing, T. Thaler, P. Knochel, Org. Lett. 2006, 8, 1125-1128; e) E.-K. Shin, H. J. Kim, Y. Kim, Y. Kim, Y. S. Park, Tetrahedron Lett. 2006, 47, 1933-1935; f) L.-T. Yu, M.-T. Ho, C.-Y. Chang, T.-K. Yang, Tetrahedron: Asymmetry 2007, 18, 949-962; g) A. Tarui, D. Ozaki, N. Nakajima, Y. Yokota, Y. S. Sokeirik, K. Sato, M. Omote, I. Kumadaki, A. Ando, Tetrahedron Lett. 2008, 49, 38393843; h) M. Fornalczyk, K. Singh, A. M. Stuart, Chem. Commun. 2012, 48, 3500-3502; i) F. Grellepois, J. Org. Chem. 2013, 78, 1127-1137.

[5] a) M. A. Fernández-Ibáñez, B. Maciá, D. A. Alonso, I. M. Pastor, Eur. J. Org. Chem. 2013, 7028-7034; b) P. G. Cozzi, Pure Appl. Chem. 2008, $80,891-901$. For a recent review on diastereoselective Reformatsky-type reactions, see: c) S. Choppin, L. Ferreiro-Medeiros, M. Barbarotto, F. Colobert, Chem. Soc. Rev. 2013, 42, 937-949.

a) P. G. Cozzi, Angew. Chem. 2006, 118, 3017-3020; Angew. Chem. Int. Ed. 2006, 45, 2951-2954; b) P. G. Cozzi, A. Mignogna, L. Zoli, Synthesis 2007, 17, 2746-2750; c) P. G. Cozzi, F. Benfatti, M. Guiteras Capdevila, A. Mignogna, Chem. Commun. 2008, 3317-3318; d) F. Benfatti, P. G. Cozzi, Tetrahedron: Asymmetry 2010, 21, 1503-1506.

[7] a) M. A. Fernández-lbáñez, B. Maciá, A. J. Minnaard, B. L. Feringa Angew. Chem. 2008, 120, 1337-1339; Angew. Chem. Int. Ed. 2008, 47, 1317-1319; b) M. A. Fernández-lbáñez, B. Maciá, A. J. Minnaard, B. L. Feringa, Chem. Commun. 2008, 2571-2573; c) M. A. Fernández-lbáñez, B. Maciá, A. J. Minnaard, B. L. Feringa, Org. Lett. 2008, 10, 4041-4044.

[8] H. Gilman, M. Speeter, J. Am. Chem. Soc. 1943, 65, 2255-2256.

[9] a) J. C. Adrian, Jr., J. L. Barkin, L. Hassib, Tetrahedron Lett. 1999, 40, 2457-2460; b) J. C. Adrian, Jr., M. L. Snapper, J. Org. Chem. 2003, 68, 2143-2150; c) J. C. Adrian, Jr., J. L. Barkin, R. J. Fox, J. E. Chick, A. D Hunter, R. A. Nicklow, J. Org. Chem. 2000, 65, 6264-6267; d) C.-R. Cao, M. Jiang, J.-T. Liu, Eur. J. Org. Chem. 2015, 1144-1151; e) H. Rodríguez-Solla, A. Díaz-Pardo, C. Concellón, V. del Amo, Synlett 2014, 25, 1709-1712; f) C. Q. Fontenelle, M. Conroy, M. Light, T. Poisson, X.Pannecoucke, B. Linclau, J. Org. Chem., 2014, 79, 4186-4195.

[10] For reviews on asymmetric synthesis of $\beta$-amino acids, see: a) J.-A. Ma Angew. Chem. 2003, 115, 4426-4435; Angew. Chem. Int. Ed. 2003, 42, 4290-4299; b) M. Liu, M. P. Sibi, Tetrahedron, 2002, 58, 7991-8035; c) G. Cardillo, C. Tomasini, Chem. Soc. Rev. 1996, 25, 117-128; d) B. Weiner, W. Szymanski, D. B. Janssen, A. J. Minnaard, B. L. Feringa, Chem. Soc. Rev. 2010, 39, 1656-1691. 
[11] a) L. Gerald, D. Seebach, Biopolymers 2004, 76, 206-243; b) D. Seebach, T. Kimmerlin, R. Sebesta, M. A. Campo, A. K. Beck, Tetrahedron 2004, 60, 7455-7506; c) D. Seebach, J. Gardiner, Acc. Chem. Res., 2004, 41, 1366-1375.

[12] a) Chemistry and Biology of $\beta$-Lactam Antibiotics, Vol. 1-3 (Eds.:R. B. Morin, M. Goldman), Academic Press, New York, 1982; b) Antibiotics containing the $\beta$-Lactam Structure, Parts $1 \& 2$ (Eds.: A. L. Demain, N. A Solomon), Springer, Berlin, 1983; c) D. J. Waxman, J. L. Strominger Annu. Rev. Biochem. 1983, 52, 825-869; d) D. J. Hart, D.-C. Ha, Chem Rev., 1989, 89, 1447-1465; e) C. R. Pitts, T. Lectka, Chem. Rev., 2014 114, 7930-7953

[13] P. G. Cozzi, Adv. Synth. Catal. 2006, 348, 2075-2079.

[14] For enantioselective aza-Reformatsky reaction using stoichometric amounts of chiral ligand, see: a) P. G. Cozzi, E. Rivalta, Angew. Chem. 2005, 117, 3666-3669; Angew. Chem. Int. Ed. 2005, 44, 3600-3603; b) A. Tarui, H. Nishimura, T. Ikebata, A. Tahira, K. Sato, M. Omote, H. Minami, Y. Miwa, A. Ando, Org. Lett., 2014, 16, 2080-2083.

[15] a) S. J. Kim, M.-H. Jung, K. H. Yoo, J.-H. Cho, C.-H. Oh, Bioorg. Med. Chem. Lett., 2008, 5815-5818; b) S. J. Kim, H. B. Park, J. S. Lee, N. H. Jo, K. H. Yoo, D. Baek, B.-W. Kang, J.-H. Cho, C.-H. Oh, Eur. J. Med. Chem., 2007, 1176-1183; c) S. R. Hanson, L. J. Whalen, C.-H. Wong, Bioorg. Med. Chem., 2006, 8386-8395; d) Y. G. Liu, W. B. Xiao,M. K. Wong, C. M. Che, Org. Lett., 2007, 9, 4107-4110; e) B. Alig, K. H. Müller E.-M. Franken, U. Görgens, A. Voerste, WO 2010072310, 2010; f) S Petry, K. H. Baringhaus, S. Hölder G. Mueller, WO 2002011722, 2002.

[16] For reviews, see: a) R. E. Meléndez, W. D. Lubell, Tetrahedron, 2003, 59, 2581-2616; b) J. F. Bower, J. Rujirawanicha, T. Gallagher, Org. Biomol. Chem., 2010, 8, 1505-1519.

[17] For the enantioselective addition of organoboron compounds, see: a) T.S. Zhu, J.-P. Chen, M.-H. Xu, J. Am. Chem. Soc., 2013, 135, 971-974 b) H. Wang, M.-H. Xu, Synthesis, 2013, 2125-2133; c) C. Jiang, Y. Lu, T. Hayashi, Angew. Chem., 2014, 126, 10091-10097; Angew. Chem., Int. Ed., 2014, 53, 9936-9939; d) H. B. Hepburn, H. W. Lam, Angew. Chem. 2014, 126, 11789-11794; Angew. Chem., Int. Ed., 2014, 53, 1160511610; e) Y. Luo, H. B. Hepburn, N. Chotsaeng, H. W. Lam, Angew. Chem., 2012, 124, 8434-8438; Angew. Chem., Int. Ed., 2012, 51, 83098313; f) H. B. Hepburn, N. Chotsaeng, Y. Luo H. W. Lam, Synthesis, 2013, 2649-2661; g) Y. Luo, A. J. Carnell, H. W. Lam, Angew. Chem., 2012, 124, 6866-6870; Angew. Chem., Int. Ed., 2012, 51, 6762-6766; h) J. I. Martínez, J. J. Smith, H. B. Hepburn, H. W. Lam, Angew. Chem., 2016, 128, 1120-1124; Angew. Chem., Int. Ed. 2016, 55, 1108-1112; i)
M. Quan, G. Yang, F. Xie, I. D. Gridnev, W. Zhang, Org. Chem. Front., 2015, 2, 398-402; j) R. Takechi, T. Nishimura, Org. Biomol. Chem., 2015 13, 4918-4924. For enantioselective addition of alkynes, see: k) L. de Munck, A. Monleón, C. Vila, M. C. Muñoz, J. R. Pedro, Org. Biomol. Chem., 2015, 13, 7393-7396. For enantioselective Mannich reactions, see: I) Y.-Q. Wang, X.-Y. Cui, Y.-Y. Ren, Y. Zhang, Org. Biomol. Chem. 2014, 12, 9101-9104; m) H.-X. Zhang, J. Nie, H. Cai, J.-A. Ma, Org. Lett., 2014, 16, 2542-2545; n) C.-M. Jia, H.-X. Zhang, J. Nie, J.-A. Ma, J. Org Chem. 2016, 81, 8561-8569. For enantioselective cycloadditions, see: o) H. Yu, L. Zhang, Z. Li, H. Liu, B. Wang, Y. Xiao, H. Guo, Tetrahedron, 2014, 70, 340-348; p) L. Zhang, H. Yu, Z. Yang, H. Liu, Z. Li, J. Guo, Y. Xiao, H. Guo, Org. Biomol. Chem., 2013, 11, 8235-8240; q) Y. Liu, T.-R. Kang, Q.-Z. Liu, L.-M. Chen, Y.-C. Wang, J. Liu, Y.-M. Xie, J.-L. Yang, L. He, Org. Lett., 2013, 15, 6090-6093. For a Friedel-Crafts, see: r) M Montesinos-Magraner, R. Cantón, C. Vila, G. Blay, I. Fernández, M. C. Muñoz, J. R. Pedro, RSC Adv., 2015, 5, 60101-60105.

[18] Ethyl bromoacetate was unreactive under the reaction conditions.

[19] For an asymmetric Reformatsky reaction using indolinylmethanol ligands, see: N. Lin, M.-M. Chen, R.-S. Luo, Y.-Q. Deng, G. Lu, Tetrahedron: Asymmetry, 2010, 21, 2816-2824.

[20] M. Kitamura, S. Suga, M. Niwa, R. Noyori, J. Am. Chem. Soc. 1995, 117, 4832-4842

[21] When 1 eq. of TEMPO was added to the reaction, only $7 \%$ of conversion was observed indicating the presence of radicals.

[22] E. Mileo, F. Benfatti, P. G. Cozzi, M. Lucarini, Chem. Commun. 2009, 469-470.

[23] Oxygen-centered radicals ( $\mathrm{MeO}^{\circ}$ ) cannot be ruled out as an initiating species in the aza-Reformatsky reaction mediated by $\mathrm{Me}_{2} \mathrm{Zn} / a i r$, see: $\mathrm{M}$. Kubisiak, K. Zelga, W. Bury, I. Justyniak, K. Budny-Godlewski, Z. Ochal, J. Lewinski, Chem. Sci. 2015, 6, 3102-3108.

[24] See supporting information for further details.

[25] The absolute configuration for compounds 3, was determined $S$ by chemical correlation of compound $\mathbf{8 a}$.

[26] The absolute configuration of the stereogenic center of compounds 5 was determined to be $(S)$ on the basis of X-ray crystallographic analysis of compound $\mathbf{5 f}$. CCDC-1503457 (for $\mathbf{5 f}$ ) contains the supplementary crystallographic data. These data can be obtained free of charge from The Cambridge Crystallographic Data Centre via www.ccdc.cam.ac.uk/data_request/cif. 
Entry for the Table of Contents (Please choose one layout)

Layout 2:

\section{COMMUNICATION}

Lode De Munck, Carlos Vila* M. Carmen Muñoz and José R. Pedro*

Page No. - Page No.

Catalytic Enantioselective AzaReformatsky Reaction with Cyclic Imines 